\title{
The Epiphytic Cactaceae Hylocereus setaceus (Salm-Dick ex DC.) Ralf Bauer Seed Germination is Controlled by Light and Temperature
}

\author{
Edson Simão, Fábio Socolowski and Massanori Takaki* \\ Departamento de Botânica, Caixa Postal 199, UNESP, Rio Claro, 13506-900, São Paulo, Brasil
}

\begin{abstract}
The effect of light and temperature on seed germination in Hylocereus setaceus was analyzed by isothermic incubations under continuous white light and darkness. The minimum temperature for germination was between 5 to $10^{\circ} \mathrm{C}$ and the maximum between 45 to $50^{\circ} \mathrm{C}$. The optimum temperaturewais between 25 and $30^{\circ} \mathrm{C}$. The involvement of phytochrome, by very low fluence response, in controlled seed germination was attained by incubation in a gradient of photoequilibrium of phytochrome. The results indicated that seeds of $H$. setaceus germinated in a wide range of temperature, under canopy and in open areas, but in complete darkness they did not germinate.
\end{abstract}

Key words: Endangered cactus, phytochrome, seed germination

\section{INTRODUCTION}

The distribution of plant species in natural environment can be associated to variations in the habitat, such as canopy alteration and consequently the water availability and temperature variations, and to the germination of seeds which can influence the population of the species in the area (Raich, 1990). These variations in the environment in are important factors to be considered in the classification by the rarity degree in cactacean (Ramírez-Padilla and Valverde, 2005). For another species, this variation in the environment can not influence the germination process, but the survivor of their seedlings (Rimer and Mccue, 2005). The high sensitivity of seeds to the environmental conditions results in the higher probability of germination where their seedling surviving is high (Ramírez-Padilla and Valverde, 2005).
The specific requirement for seed germination can be associated to the form of life for each species, to the environment where the plant will be established and to the seed mass (Rójas-Aréchiga et al., 1997; Flores and Briones, 2001). According to Pearson et al. (2003) small seeds usually respond positively to the light fluences, while large seeds usually respond positively to temperature fluctuations.

Photoblastic responses usually are related to the habit of the plant (Vázquez-Yanes and OroscoSegovia, 1990). The light sensitivity for seeds is dependent on phytochrome action and this sensitivity changes with the incubation temperature (Smith, 1975). In some species, changes in temperatures can overcome light requirement for germination as reported by Sugahara and Takaki (2004) in Psidium guajava. Several studies have been done with species which live in arid environments in Mexico (Gordínez-

\footnotetext{
${ }^{*}$ Author for correspondence
} 
Alvarez and Valiente-Banuet, 1998; RojasAréchiga et al., 1997, 2001; Flores and Briones, 2001; Oliveira-Carrillo et al, 2003; BénitezRodríguez et al., 2004, Ramírez-Padilla and Valverde, 2005).

Usually cactacean species present light sensitive seeds and germinate in a wide range of temperature, being indifferent to changes in temperatures (Oliveira-Carrillo et al, 2003; RojasAréchiga and Vázquez-Yanes, 2000; BénitezRodríguez et al, 2004). Several species of cactacean present edible fruits and some of them are cultivated, such as Stenocereus stellatus (Rojas-Aréchiga et al, 2001) and Opuntia ficusindica (L.) Miller, currently cultivated in Brazil. Hylocereus undatus (Haw.) Britton and Rose, commonly known as dragon fruit, strawberry pear and pitaya is the name of both plants and their fruits are cultivated cactacean, especially in Colombia and Mexico, as edible fruits (Andrade et al., 2005). Pitaya is usually cultivated as stem canopy trained into two layers, or by the use of horizontal trellises and on the ground with supports (Zee et al., 2004). The main characteristics of $H$. setaceus are stems usually climbing on trees or clambering over rocks with aerial roots and on. The flowers, with 25 to $30 \mathrm{~cm}$ long, present outer perianth-segments linear and green widely spreading and the inner perianthsegments erect, broader than outer segments. The edible fruits somewhat pointed $(7 \mathrm{~cm}$ long) with black seeds (Britton and Rose, 1937).

Considering the importance of epiphytic cactacean in tropical forest, especially for attracting dispersers and consequently the maintenance of the biodiversity, germination of $H$. setaceus seeds was studied under light and temperature controls, which according to The New York Botanical Gardens is considered an endangered or threatened species.

\section{MATERIAL AND METHODS}

Fruits of $H$. setaceus were harvested from three plants, in a fragment of seasonal semidecidual forest located at São Tomás de Aquino, MG, Brazil. The fruits were depulped on a sieve and the seeds were washed under tap water. For depulping process, the $\mathrm{pH}$ of water wwas decreased with small doses of acetic acid and immediately washed with current tap water to remove mucilage firmly adhered to the seeds. After this process, the seeds were put to dry at room temperature and stored at $10^{\circ} \mathrm{C}$ in a sealed glass bottle. The mass of 1000 seeds of $H$. setaceus was $2.80 \pm 0.0424 \mathrm{mg}$ (mean \pm standard deviation) (Brasil, 1992).

For germination experiments, thirty seeds on two layers of water imbibed filter paper in each of four $50 \mathrm{~mm}$ diameter Petri dishes were used. For white light treatment, the Petri dishes were put inside colorless plastic boxes (gerboxes) under fluorescent lamps and for dark treatment inside black gerboxes. Isothermic incubations were carried out inside germinators (FANEM, MARCONI, SP, Brasil) in the range of 5 to $50^{\circ} \mathrm{C}$ with $5^{\circ} \mathrm{C}$ intervals, under both white light and darkness. White light was obtained with the aid of two $20 \mathrm{~W}$ day-light fluorescent lamps with fluence of $32.85 \mu \mathrm{mol} . \mathrm{m}^{-2} . \mathrm{s}^{-1}$ at seed level. Seeds with at least $1 \mathrm{~mm}$ long root were considered as germinated.

The effect of phytochrome photoequilibrium on seed germination was carried out according to Sugahara and Takaki (2004) at $25^{\circ} \mathrm{C}$. The effect of white light photoperiod was determined at $25^{\circ} \mathrm{C}$ inside germinators in the range of 2 to $12 \mathrm{~h}$ daily light. The germinated seeds were daily scored. The dark incubated seeds and effect of photoequilibrium of phytochrome experiments were scored under dim green safe light (AmaralBaroli and Takaki, 2001). The spectra of light were obtained with the aid of a LI-1800 spectroradiometer (LI-COR, U.S.A.). The theoretical photoequilibrium of phytochrome $(\varphi)$ was calculated according to Mancinelli (1994).

Relative frequency of germination $(\mathrm{RF}=\mathrm{ni}: \mathrm{Nt}$, where $\mathrm{ni}$ is the number of germinated seeds between timers ti-1 and ti and $\mathrm{Nt}$ is the total number of germinated seeds); germination rate (GR $=1: t$, where $t$ is the mean time, calculated as $\mathrm{t}=\left(\sum\right.$ ni.ti): $\Sigma$ ni) and synchronization index (U=$\Sigma$ RF. $\log _{2} R F$, where RF is the relative frequency of germination) were calculated according to Labouriau and Osborn (1984). The data were analyzed by Tukey test at $\alpha=0.05$ after transformation of germination data to arcsin of $\%$, where $\%$ was the percentage germination divided by 100 . When results did not present normality and homogeneity, the data were analyzed by Kruskal-Wallis test (Sokal and Rohlf, 1981). 


\section{RESULTS AND DISCUSSION}

Seeds of $H$. setaceus germinated in a wide range of temperature with maximum percentage germination obtained in the range of 15 to $40^{\circ} \mathrm{C}$, reaching $100 \%$ at $25^{\circ} \mathrm{C}$. No germination was observed at 5 and $50^{\circ} \mathrm{C}$. The minimum temperature was between 5 to $10^{\circ} \mathrm{C}$ and the maximum between 45 to $50^{\circ} \mathrm{C}$ under continuous white light (Fig. 1). The germination rates were also similar in the range of temperatures of 25 to $30^{\circ} \mathrm{C}$. Although the germination rate at $45^{\circ} \mathrm{C}$ was the highest, only $7.5 \%$ of seeds germinated (Fig. 1). The germination of cactacean seeds, usually, is a fast event (Górdinez-Alvarez and Valiente-Banuet, 1998; Ramírez-Padilla and Valverde, 2005), since the process occurs when water is available and in arid environments it can be a short event, and the time for complete imbibition of seeds is also short leading to the high germination rate (Naranjo et al., 2003). According to Labouriau (1983) the cardinal temperatures reflect the geographical distribution of species. However, in some species it is not true, as reported by Santos et al. (2005) in Tabebuia serratifolia, with restricted distribution, presents wide range of temperature where seeds can germinate than Tabebuia chrysotricha with wide distribution and minor range of temperature. Andrade et al. (2005) reported that seeds of $H$. undatus presented high percentage germination at $25^{\circ} \mathrm{C}$, reaching the maximum in a period of one week incubation, since the first score was done after 7 days. In present work maximum percentage germination was reached between third to fourth days from sowing (Fig. 1).

$\underline{\text { Table } 1 \text { - Effect of temperature and white light on the synchronization indexes. }}$

\begin{tabular}{ccc} 
& \multicolumn{3}{c}{ Synchronization Index (bits) } \\
\hline $5^{\circ} \mathrm{C}$ & Light & Darkness \\
\cline { 2 - 3 } $10^{\circ} \mathrm{C}$ & - & - \\
$15^{\circ} \mathrm{C}$ & $0.500 \mathrm{a}$ & - \\
$20^{\circ} \mathrm{C}$ & $3.497 \mathrm{c}^{*}$ & - \\
$25^{\circ} \mathrm{C}$ & $2.136 \mathrm{~b}$ & $0.017 \mathrm{a}$ \\
$30^{\circ} \mathrm{C}$ & $2.057 \mathrm{~b}$ & $0.283 \mathrm{a}$ \\
$35^{\circ} \mathrm{C}$ & $1.797 \mathrm{~b}$ & - \\
$40^{\circ} \mathrm{C}$ & $2.445 \mathrm{bc}$ & $0.017 \mathrm{a}$ \\
$45^{\circ} \mathrm{C}$ & $3.140 \mathrm{c}$ & $0.050 \mathrm{a}$ \\
$50^{\circ} \mathrm{C}$ & $0.493 \mathrm{a}$ & $0.526 \mathrm{a}$ \\
\hline
\end{tabular}

*. Different letters indicate differences by Tukey test

- . no germination observed

The highest synchronization of germination (lowest synchronization index) were obtained in the range of 20 to $35^{\circ} \mathrm{C}$, showing that the optimum temperature was in this range of temperature for seeds germination of $H$. setaceus (Table 1). Considering the data of germinability, germination rate and synchronization index the optimum temperature for seed germination of $H$. setaceus was between 25 and $30^{\circ} \mathrm{C}$ under white light (Fig. 1A and C). Rojas-Aréchiga et al. (1998) reported that in Ferocactus recurvus the maximum germination was attained only at $25^{\circ} \mathrm{C}$.

The germination of cactacean seeds occur usually in the range of 20 to $30^{\circ} \mathrm{C}$ (Rójas-Achériga and Vázquez-Yanes, 2000) as in Stenocereus stellatus (Rójas-Aréchiga et al., 2001) and in Stenocereus 
queretaroensis (De La Barreira and Nobel, 2003). But seeds of $H$. setaceus germinated well in a wide range from 15 to $40^{\circ} \mathrm{C}$ under white light. Under darkness, low germination was attained at 20 and $25^{\circ} \mathrm{C}$ and in the range from 35 to $45^{\circ} \mathrm{C}$ (Fig. 1B and D). This effect of light promoting cactacean seed germination was reported in Pachycereus pringlei (Nolasco et al., 1996), Echinocactus platyacanthus, Ferocactus robustus, Ferocactus flavovirens, Ferocactus recurvus (Rójas-Aréchiga et al., 1997), Stenocereus queretaroensis (Pimienta-Barrios et al., 2004) and Ferocactus wislizeni (Bowers, 2000). According to RojasAréchiga et al. (2001) the light requirement for germination could be related to the seed mass, as reported to Stenocereus stellatus. Rójas-Arechiga et al. (1997) reported that seeds of Pachyrocereus hollianus, Cephalocereus chrysacanthus and
Neobuxbaumia tetetzo germinated under white light, darkness, far-red and red light conditions. The germination under all tested condition by Rójas-Arechiga (1997) indicated the participation of phytochrome A, as suggested by Takaki (2001) in light insensitive seeds.

The results indicated that phytochrome could control seed germination in $H$. setaceus. Smith (1975) reported the same effect of temperature on light sensitivity by seeds in Lactuca sativa. At $45^{\circ} \mathrm{C}$ few seeds of $H$. setaceus germinated and did not show light sensitivity, probably due to an overriding factor not related to phytochrome (Takaki et al., 1985).

Two hours photoperiod was enough to induce maximum germination at $25^{\circ} \mathrm{C}$ with highest germination rate with increasing photoperiod (Fig. 2).

A
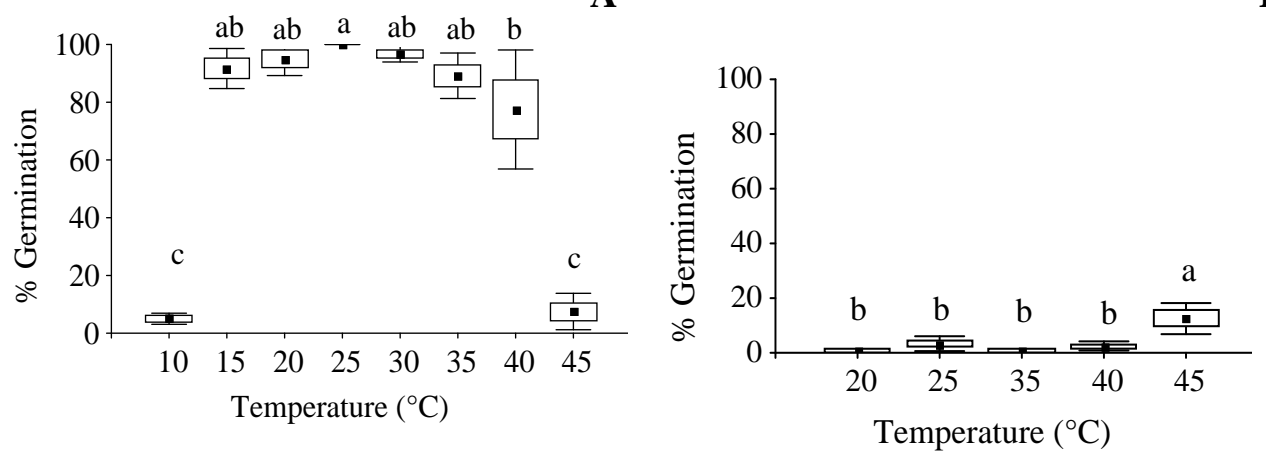

C

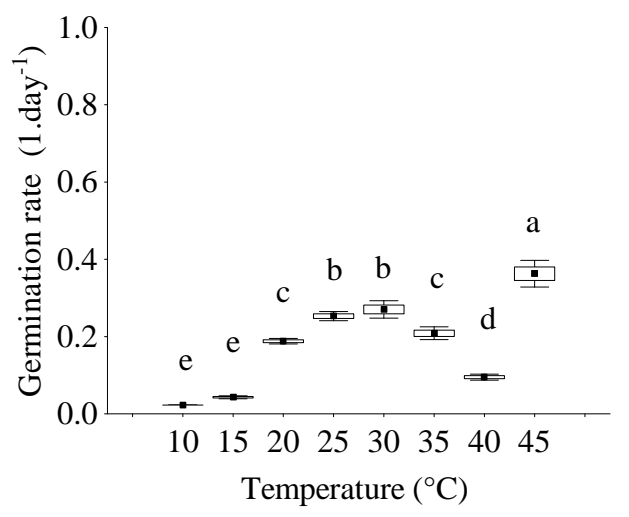

D

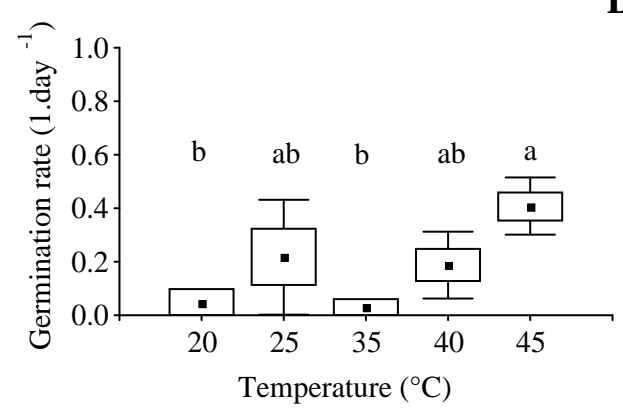

Figure 1 - Effects of temperature and white light on seed germination in Hylocereus setaceus. A and $\mathrm{C}$ represents germination under white light and $\mathrm{B}$ and $\mathrm{D}$ on darkness. The different letters on the figure indicate differences by Kruskal-Wallis test on A and D and by Tukey on B and C. Boxes on the figure represent the standard deviation and bars the standard error of the mean. Only the results of temperatures where germination occurred were plotted on B and D. 
These results indicated that seeds of $H$. setaceus presented high sensitivity to light and that they germinated in small gaps of the canopy. But if the seeds were covered by light impermeable material, such as under the bark of trees, they would not germinate.

Seeds of $H$. setaceus germinated under all tested photoequilibrium of phytochrome. Low photoequilibrium of phytochrome $(\varphi=0.03)$, which represented light filtered by dense canopy, induced 97.5\% of germination. According to Smith (1994) the canopy shade can maintain the photoequilibrium of phytochrome in the range of 0.12 to 0.69 , while the daylight in the range of 0.68 to 0.70 . This broad range in the canopy shade is due the different number of leaf layers and the physical properties of leaves of different plants. Seeds of $H$. setaceus also germinated at high percentage under high photoequilibrium of phytochrome $(\varphi=0.82)$, which represent open areas (Figs. 1 and 3). The high photoequilibrium of phytochrome was obtained by unfiltered day-light fluorescent lamps (Fig. 1). Similar results were obtained by Bénitez-Rodríguez et al. (2004) in Mammillaria haageana and Mammillaria carnea. The threshold level of light for induction of seed germination can be understood by action of different forms of phytochrome (Takaki, 2001). The germination rate showed a slight increase with increase in the photoequilibrium of phytochrome (Fig. 3). The results indicated that the germination of seeds of $H$. setaceus was controlled by light through the very low fluence response of phytochrome (Mancinelli, 1994). The control of seed germination by very low fluence indicated the involvement of phytochrome A (Casal and Sánchez, 1998) in $H$. setaceus. This high sensitivity to light was reported by several authors such as Scopel et al. (1991) in buried seeds of Datura ferox and Amaral-Baroli and Takaki (2001) in seeds of Bidens pilosa.
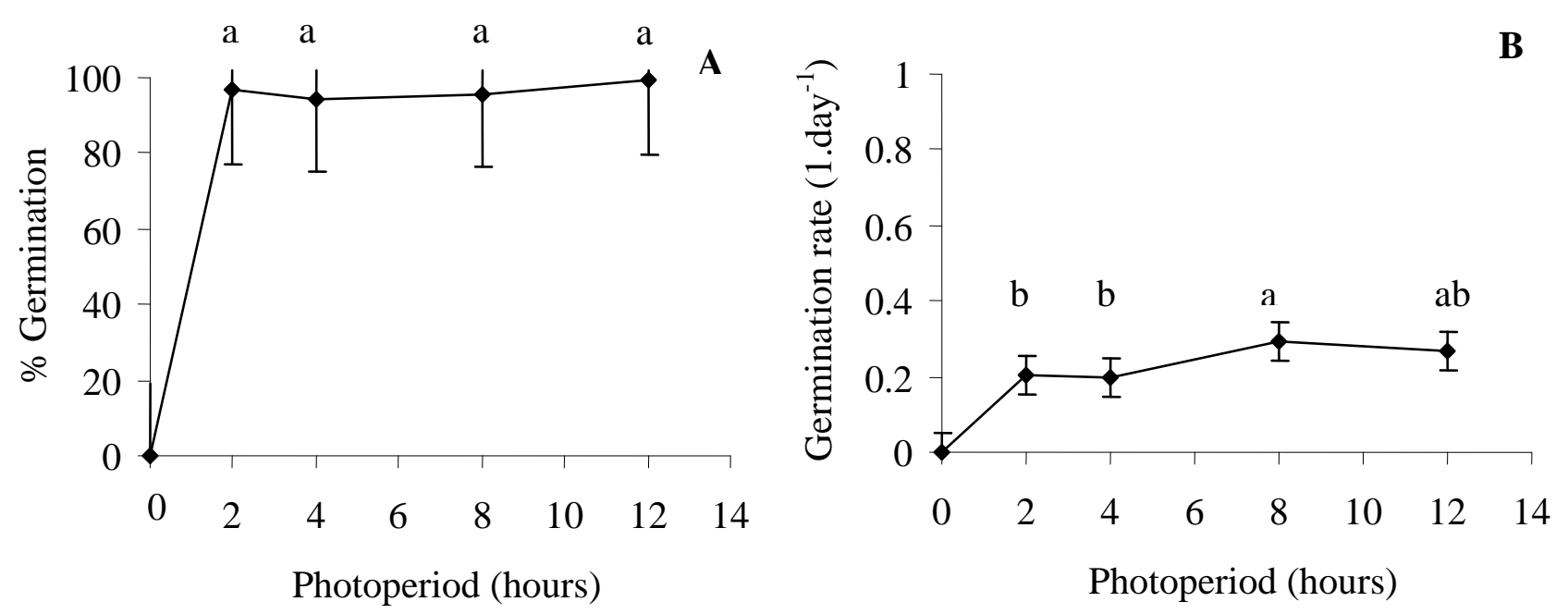

Figure 2 - Effect of photoperiod of white light at $25^{\circ} \mathrm{C}$ on seed germination in Hylocereus setaceus. A. germination percentage and B. germination rate. Means followed by the same letter are not significantly different. The different letters on the figure indicate differences by Kruskal-Wallis test. The bars on the figure represent the standard error of the mean. 


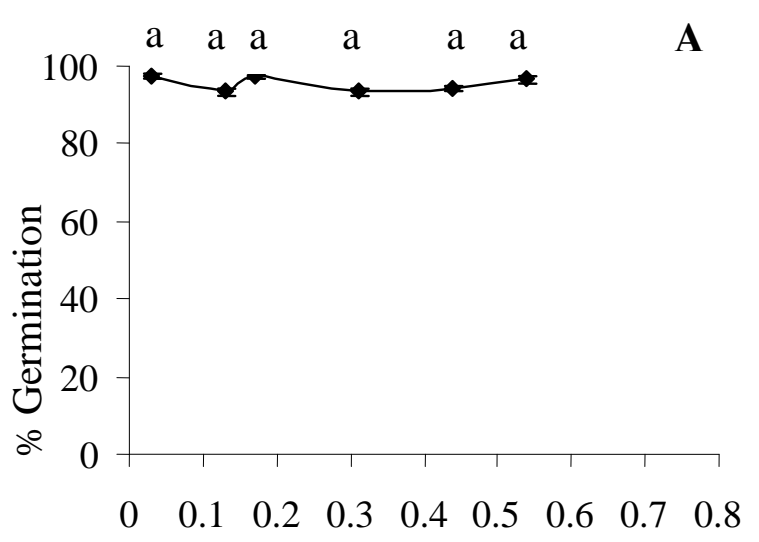

Phytochrome photoequilibrium (\%)

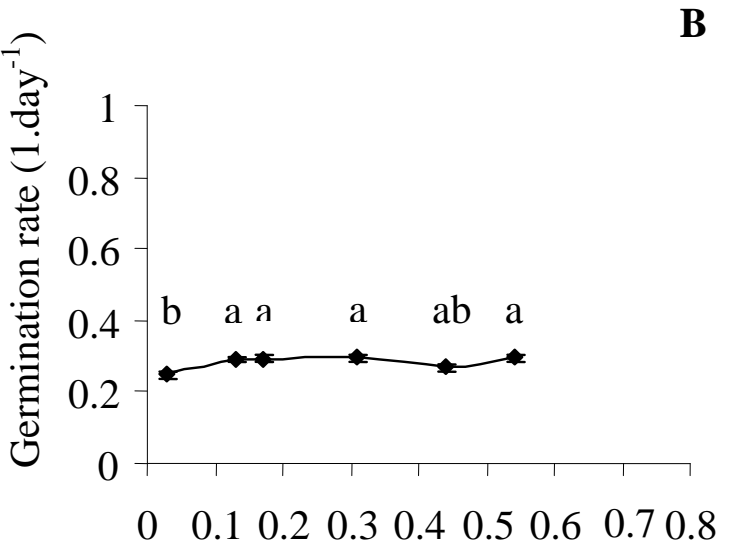

Phytochrome photoequilibrium (\%)

Figure 3 - Effect of photoequilibrium of phytochrome on seed germination in Hylocereus setaceus at $25^{\circ} \mathrm{C}$. A. germination percentage and B. germination rate. Means followed by the same letter are not significantly different. The different letters on the figure indicate differences by Kruskal-Wallis test. The bars on the figure represent the standard error of the mean. The error was very small in this experiment.

Nolasco et al. (1997) reported that the germination of seeds of Stenocereus thurberi was inhibited by full solar radiation and induced by attenuated sun light. They concluded that this inhibitory effect of full sun light was due to increase in the temperature and not due to the direct effect of light. This inhibitory effect of full sun light on seed germination could also be due to the high irradiance response of phytochrome, which was also controlled by phytochrome A (Takaki, 2001). The sensitivity of seeds to light for the germination process indicated both the environmental effects during seed formation in mother plants, as reported by Ladeira et al. (1987) in seeds of Plantago tomentosa and the gap dependence of some species for germination, as reported by Denslow (1980). Because the necessity of light, although of low fluence for germination of seeds of $H$. setaceus, the epiphytic habit of the species suggested that seed bank could be formed on the bark of some tree species in places where the light did not reach. Some reports have indicated the formation of seed bank in some cactacean, for example, Ferocactus wislizeni, a perennial desert cactus has a between-year seed bank in the soil, where viable seeds are maintained for more that 13 months (Bowers, 2000).
Thus, it could be concluded that, although $H$. setaceus was considered as an endangered species, its seeds presented mechanism for germination in a broad range of temperature and degree of canopy shading. The epiphytic habit of the species in seasonal semideciduous forest could make its seeds germinate under both open and shaded areas. Experiments on the seed bank and on seedling development must be done for the determination of the importance of the semideciduity of the forest for establishment of $H$. setaceus.

\section{RESUMO}

O efeito da luz e da temperatura sobre a germinação de sementes de Hylocereus setaceus foi analisado sob condições de incubações isotérmicas. Hylocereus setaceus é uma espécie ameaçada de extinção, que ocorre na Mata Atlântica e florestas estacionais semideciduais. A temperatura mínima para a germinação está entre 5 e $10^{\circ} \mathrm{C}$ e a máxima entre 45 e $50^{\circ} \mathrm{C}$. A temperatura ótima está entre $25^{\circ} \mathrm{C}$ e $30^{\circ} \mathrm{C}$. A participação do fitocromo, através da resposta de fluência muito baixa, no controle da germinação de sementes foi determinada através de incubações das sementes em um gradiente de fotoequilíbrio do fitocromo. 
Os resultados apresentados no presente trabalho indicam que sementes de Hylocereus setaceus germinam em uma ampla faixa de temperatura, sob a sombra de vegetação e em áreas abertas, embora não germinem em condições de ausência completa de luz.

\section{ACKNOWLEDGEMENTS}

This work was supported by grants from FAPESP and FUNDUNESP. E.S. and F.S. have CNPq Scholarships and M.T. is a CNPq Research fellow.

\section{REFERENCES}

Amaral-Baroli, A. and Takaki, M. (2001) Phytochrome controls achene germination in Bidens pilosa $\mathrm{L}$. (Asteraceae) by very low fluence response. Brazilian Archives of Biology and Technology, 44, 121-124.

Andrade, R.A., Oliveira, I.V.M. and Martins, A.B.G. (2005). Influência da condição e período de armazenamento na germinação de sementes de pitaya vermelha. Revista Brasileira de Fruticultura, 27, 168-170.

Brasil (1982) Regras para análise de sementes. Ministério da Agricultura. Brasília: SNDA/LANARV, 188p.

Benitez-Rodriguez, J. L.; Orozco-Segovia, A.; Rojas Aréchiga, M. (2004). Light effect on seed germination of four Mammillaria species from the Tehuacán-Cuicatlán Valley, central México. Southwestern Naturalist, 49, 11-17.

Bowers, J. E. (2000). Does Ferocactus wislizeni (Cactaceae) have a between-year seed bank? Journal ff Arid Environments, 45, 197-205.

Britton, N. L. and Rose, J. L. (1937).The Cactaceae: Descriptions and illustrations of plants of the cactus family. 2.ed. New York, p. 211-212.

Casal, J.J and Sánchez, R. (1998). Phytochromes and seed germination. Seed Science Research, 8, 317-329.

De La Barreira, E. and Nobel, P. S. (2003). Physiological ecology of seed germination for the columnar cactus Stenocereus queretaroensis. Journal of Arid Environments, 53, 297-306.

Denslow, J.S. (1980). Gap partitioning among tropical rainforest trees. Biotropica, 12, 47-55.

Flores, J. and Briones, O. (2001). Plant life-form and germination in a Mexican inter-tropical desert: effects of soil water potential and temperature. Journal of Arid Environments, 47, 485-497.
Gordínez-Alvarez, H. and Valiente-Banuet, A. (1998). Germination and early seedling growth of Tehuacan Valley cacti species: the role of soils and seed ingestion by dispersers on seedling growth. Journal of Arid Environments, 39, 21-31.

Labouriau, L.G. (1983) A germinação das sementes. Secretaria-Geral da OEA, Washington, 174p.

Labouriau, L.G. and Osborn, J.H. (1984). Temperature dependence of the germination of tomato seeds. Journal of Thermal Biology, 9: 285-294.

Ladeira, A.M.; Guardia, M.C. and Takaki, M. (1987). Manipulation of seed germination in Plantago tomentosa Lam. and Raphanus sativus. Seed Science and Technology, 15, 55-63.

Mancinelli, A. L. (1994). The physiology of phytochrome action. In: Kendrick, R. E. and Kronenberg, G. H. M. (Ed). Photomorphogenesis in plants. 2.ed. The Netherlands: Kluwer Academic Publishers, p.211-269.

Naranjo, M. E.; Rengifo, C.; and Soriano, J. P. (2003). Effect of ingestion by bats and birds on seed germination of Stenocereus griseus and Subpilocereus repandus (Cactaceae). Journal of Tropical Ecology, 19, 19-25.

Nolasco, H.; Veja-Vilasante, H. L.; Romero-Schmid, H. L.; Diaz-Rondero, A. (1996). The effects of salinity, acidity, light and temperature on the germination of seeds of cardón (Pachycereus pringlei (S. Wats.) Britton and Rose, Cactaceae). Journal of Arid Environments, 33, 87-94.

Nolasco, H.; Veja-Villasante, F.; Diaz-Rondero, A. (1997). Seed germination of Stenocereus thurberi (Cactaceae) under different solar irradiation levels. Journal of Arid Environments, 36, 123-132.

Oliveira-Carrillo, Y.; Márquez-Guzmán, J.; Barras, V. L.; Sánchez-Coronado, M. E. and Orozco-Segovia, A. (2003). Germination of the hard seed coated Opuntia tomentosa S.D., a cacti from the México valley. Journal of Arid Environments, 55, 29-42.

Pearson, T. R. H.; Burslem, D. F. R. P.; Mullins, C. E.; Dalling, J. W. (2003). Functional significance of photoblastic germination in neotropical pioneer trees: a seed's eye view. Funtional Ecology, 17, 394-402.

Pimienta-Barrios, E.; Pimienta-Barrios, E. and Nobel, P. S. (2004). Ecophysiology of the pitayo de Queretaro (Stenocereus queretaroensis). Journal of Arid Environments, 59, 1-17.

Raich, J. W. (1990). Effects of canopy openings on tree seed germination in a Malasian dipterocarp forest. Journal of Tropical Ecology, 6, 203-217.

Ramírez-Padilla, C. A. and Valverde, L. (2005). Germination responses of three congeneric cactus species (Neobuxbaumia) with differing degrees of rarity. Journal of Arid Environments, 61, 333-343.

Rimer, R.L. and McCue, K.A. (2005). Restoration of Helenium virginicum Blake, a threatened plant of the Ozark Highlands. Natural Areas Journal, 25, 86-90. 
Rojas-Aréchiga, M.; Casas, A. and Vázquez-Yanes, C. (2001). Seed germination of wild and cultivated Stenocereus stellatus (Cactaceae) from the TehuacánCuicatlán Valley, Central México. Journal of Arid Environments, 49, 279-287.

Rojas-Aréchiga, M.; Orosco-Segovia, A. and VázquezYanes, C. (1997). Effect of light on germination of seven species of cacti from the Zapotitlán Valley in Puebla, méxico. Journal of Arid Environments, 36, 571-578.

Rojas-Aréchiga, M.; Vázquez-Yanes, C. and OroscoSegovia, A. (1998). Seed response to temperature of Mexican cacti species from two life forms: an ecophysiological interpretation. Plant Ecology, 135, 207-214.

Rojas-Aréchiga, M. and Vázquez-Yanes, C. Cactus seed germination: a review. Journal of Arid Environments, 44, 85-104.

Santos, D.L.; Sugahara, V. and Takaki, M. (2005). Efeitos da luz e da temperatura na germinação de sementes de Tabebuia serratifolia (Vahl) Nich, Tabebuia chrysotricha(Mart. Ex DC.) Standl. e Tabebuia roseo-alba (Ridl.) Sand - Bignoniaceae. Ciência Florestal, 15, 87-92.

Scopel, A.L.; Ballaré, C.L. and Sánchez, R.A. (1991). Induction of extreme light sensitivity in buried weed seeds and its role in the perception of soil cultivations. Plant, Cell and Environment, 14, 501508.

Sokal, R.R. and Rohlf, F. J. (1981). Biometry. New York: W.H. Freeman.
Smith, H. (1975). Phytochrome and Photomorphogenesis: an introduction to the photocontrol of plant development. Mc Graw. Hill Company, London, New York.

Smith, H. (1994). Sensing the light environment: the function of the phytochrome family. In: Kendrick, R. E. and Kronenberg, G. H. M. (Ed). Photomorphogenesis in plants. 2.ed. The Netherlands: Kluwer Academic Publishers, p. 377416.

Sugahara, V.Y. and Takaki, M. (2004). Effect of light and temperature on seed germination in guava (Psidium guajava L. - Myrtaceae). Seed Science and Technology, 32, 759-764,

Takaki, M., Heeringa, G.H., Cone, J.W. and Kendrick, R.E. (1985). Analysis of the effect of light and temperature on the fluence response curves for germination of Rumex obtusifolius. Plant Physiology, 77, 731-734.

Takaki, M. (2001) New proposal of classification of seeds by forms of phytochrome instead of photoblastism. Brazilian Journal of Plant Physiology, 13, 103-107.

Vázquez-Yanes, C. and Orozco-Segovia, A. (1990). Ecological significance of light controlled seed germination in two contrasting tropical habitats. Oecologia, 83, 171-175.

Zee, F.; Yen, C.R. and Nishima, M. (2004). Pitaya (dragon fruit, strawberry pear). Fruits and Nuts, F\&N-9, 1-3. 